\title{
Limited impact of Delta variant's mutations in the effectiveness of neutralization conferred by natural infection or COVID-19 vaccines in a Latino population
}

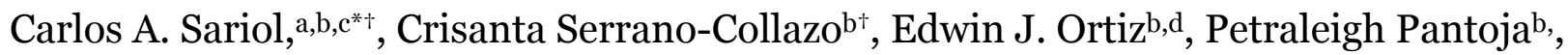
Lorna Cruz ${ }^{\mathrm{a}, \mathrm{b}}$, Teresa Arana a,b, Dianne Atehortua ${ }^{\mathrm{d}}$, Christina Pabon-Carrero ${ }^{\mathrm{d}, \#}$ and Ana M. Espino ${ }^{\mathrm{a}^{\dagger}}$

a Department of Microbiology and Medical Zoology, University of Puerto Rico-Medical Sciences Campus, San Juan, PR, USA, b Unit of Comparative Medicine, University of Puerto Rico-Medical Sciences Campus, San Juan, PR, USA, c Department of Internal medicine, University of Puerto Rico-Medical Sciences Campus, San Juan, PR, USA, d Puerto Rico Science, Technology and Research Trust, PR, USA.

${ }^{\dagger}$ These authors have contributed equally to this work and share first authorship.

*Address correspondence to Carlos A. Sariol carlos.sariol1@upr.edu

Keywords: SARS-CoV-2, COVID-19 Vaccine, Neutralization, Serology, Protection

\# current address: Latin Clinical Trial Center, San Juan, Puerto Rico, USA 
medRxiv preprint doi: https://doi.org/10.1101/2021.10.25.21265422; this version posted October 26, 2021. The copyright holder for this preprint (which was not certified by peer review) is the author/funder, who has granted medRxiv a license to display the preprint in perpetuity. It is made available under a CC-BY-NC-ND 4.0 International license.

\section{Abstract}

2 The SARS-CoV-2 pandemic has impacted public health systems all over the world. The

3 Delta variant seems to possess enhanced transmissibility, but no clear evidence suggests

4 it has increased virulence. Our data shows that pre-exposed individuals had similar

5 neutralizing activity against the authentic COVID-19 strain and the Delta and Epsilon

6 variants. After one vaccine dose, the neutralization capacity expands to all tested variants.

7 Healthy vaccinated individuals showed a limited breadth of neutralization. One vaccine

8 dose induced similar neutralizing antibodies against the Delta compared to the authentic

9 strain. However, even after two doses, this capacity only expanded to the Epsilon variant. 
medRxiv preprint doi: https://doi.org/10.1101/2021.10.25.21265422; this version posted October 26, 2021. The copyright holder for this preprint (which was not certified by peer review) is the author/funder, who has granted medRxiv a license to display the preprint in perpetuity. It is made available under a CC-BY-NC-ND 4.0 International license .

\section{Background}

11 Coronavirus disease 2019 (COVID-19), caused by the novel severe acute respiratory

12 syndrome coronavirus 2 (SARS-CoV-2), is responsible for the most recent global

13 pandemic declared by the World Health Organization (WHO) on March 11, 2020 [1]. As

14 of October 10, 2021, a total of $6,364,021,792$ vaccine doses have been administered

15 worldwide [2]. Despite the tremendous milestone achieved by vaccine approval and

16 administration, SARS-CoV-2, being an RNA virus, has genetically evolved over time

17 leading to the emergence of several variants from different geographic regions [3, 4]. The

18 variant strains have developed characteristics that grant them advantages to maintain

19 viral circulation, such as higher transmissibility and infectivity [5]. Most of these genetic

20 differences are observed in the spike protein (S) region, specifically in the receptor-

21 binding domain (RBD) and the N-terminal domain (NTD). The RBD, and to some extent

22 the NTD as suggested by some evidence, is immunodominant, serving as the main

23 neutralization target by natural and vaccine-elicited antibodies [3, 6]. The Delta variant

24 was first reported in the Indian state of Maharashtra in December 2020 and harbors ten

25 mutations (T19R, G142D, 156del, 157del, R158G, L452R, T478K, D614G, P681R, D950N)

26 in the $\mathrm{S}$ protein [3]. Of notice, the Delta variant lacks E484Q, a significant mutation

27 associated with antibody neutralization resistance [7]. After successfully spreading

28 globally, the prevalence of the Delta variant in the USA increased from $1.3 \%$ to $94.4 \%$ by

29 July 31, 2021 while the Alpha variant decreased from $70 \%$ to $2.4 \%$ [4]. But perhaps of

30 most serious concern, the Delta variant has been associated with breakthrough infections

31 in vaccinated individuals [4]. The recent surge of cases despite extensive vaccination

32 campaigns supports the concern about low vaccine effectiveness against variants. Studies

33 are at odds regarding this topic, with some claiming that breakthrough infections are

34 more likely to occur due to viral escape from antibodies [8], while others have 
medRxiv preprint doi: https://doi.org/10.1101/2021.10.25.21265422; this version posted October 26, 2021. The copyright holder for this preprint (which was not certified by peer review) is the author/funder, who has granted medRxiv a license to display the preprint in perpetuity. It is made available under a CC-BY-NC-ND 4.0 International license .

35 demonstrated mRNA vaccines remain effective [9]. But still, limited studies are

36 discerning the efficacy of the natural immune response to SARS-CoV-2 vs. the mRNA

37 vaccine-elicited response. Our most recent work confirms that following a natural

38 infection, neutralizing antibody (nAbs) titers generated during infection accompanied by

39 vaccination are significantly better in function than those generated by vaccination alone

40 [10]. To this end, in this study we compared the neutralization capacity of infected

41 vaccinated individuals and healthy vaccinated ones before and after vaccination against

42 several Variants of Concern (VoC) using a surrogate viral neutralization assay [11]. Our

43 results from a Latino population indicate that, compared with vaccination, natural

44 infection induces a broader humoral response offering a wider range of protection against

45 a rapidly evolving virus. These findings have pivotal implications in the understanding of

46 the immune response to COVID-19 induced by vaccination amid emerging variants in the

47 setting of a vaccinated population, and contribute to future vaccine designs and booster

48 schedules.

Methods

\section{Study Samples}

52 We selected individuals infected with SARS-CoV-2 any time between March 2020 and

53 February 2021. From 59 subjects followed for months, a subgroup of 10 vaccinated

54 subjects previously exposed to SARS-CoV-2 and a subgroup of 21 healthy-vaccinated

55 volunteers, that were never exposed to SARS-CoV-2, were followed for six to eight

56 months. Vaccinated subjects received either the Pfizer-BioNTech or Moderna vaccine

57 formulations. In the exposed group, all individuals tested positive for SARS-CoV-2

58 infection by quantitative PCR with reverse transcription (qRT-PCR) or serology tests

59 (IgM and/or IgG). Serum samples from both groups were collected before vaccination 
medRxiv preprint doi: https://doi.org/10.1101/2021.10.25.21265422; this version posted October 26, 2021. The copyright holder for this preprint (which was not certified by peer review) is the author/funder, who has granted medRxiv a license to display the preprint in perpetuity. It is made available under a CC-BY-NC-ND 4.0 International license .

60 (baseline), and after the first and second vaccine doses (Supplementary Tables 1 and 2).

61 Samples used in this study were obtained from adult volunteers ( $>21$ years old)

62 participating in the IRB approved clinical protocol "Molecular Basis and Epidemiology of

63 Viral infections circulating in Puerto Rico”, Proooo4333. Protocol was submitted to, and

64 ethical approval was given by, Advarra IRB on April 21, 2020. Participating volunteers

65 were recruited before the introduction of most of the SARS-CoV-2 variants were reported

66 as circulating in Puerto Rico. More specifically, the Delta variant was first detected on

67 June 15, $2021[12]$.

\section{cPass SARS-CoV-2 Neutralization Antibody Detection Assay}

69 To determine the neutralizing activity of antibodies against SARS-CoV-2, we used a

70 surrogate viral neutralization test (C-Pass GenScript sVNT, Piscataway NJ, USA)

71 according to the manufacturer's instructions [9-11]. The cutoff for this assay is set to $30 \%$

72 of neutralization. This assay measures the antibodies blocking the RBD-ACE2 interaction

73 and from here, inhibiting viral entry into host cells. For consistency and clarity, the

74 blocking activity is referred to throughout the text as percentage of neutralization.

\section{Statistical Methods}

76 Statistical analyses were performed using GraphPad Prism 7.0 software (GraphPad

77 Software, San Diego, CA, USA). The statistical significance between or within groups was

78 determined using two-way analysis of variance (ANOVA), one-way ANOVA (Tukey's,

79 Sidak's, or Dunnett's multiple comparisons test as post-hoc test), unpaired t-test, or

80 Wilcoxon-Mann-Whitney, to compare the means. The $p$ values are expressed in

81 relational terms with the alpha values. The significance threshold for all analyses was set

82 at 0.05 .

83

$84 \quad$ Results 
medRxiv preprint doi: https://doi.org/10.1101/2021.10.25.21265422; this version posted October 26, 2021. The copyright holder for this preprint (which was not certified by peer review) is the author/funder, who has granted medRxiv a license to display the preprint in perpetuity. It is made available under a CC-BY-NC-ND 4.0 International license .

85 Natural infection induces an effective neutralization against the Delta variant

87 To examine the neutralization ability of sera from naturally infected individuals against 88 the Wild Type (WT) SARS-CoV-2, we evaluated baseline samples from 10 volunteers. Out 89 of the 10 subjects, eight had neutralizing activity greater than $70 \%$, indicating the 90 presence of antibodies capable of blocking the RBD-ACE2 binding (Figure 1A and 91 Supplementary Table 3). The other two had neutralization degrees less than $70 \%$ but

92 greater than $30 \%$. To compare the neutralizing response elicited by WT SARS-CoV-2 to

93 other virus strains, we exposed sera from those 10 individuals to six variants (Alpha, Beta,

94 Gamma, Epsilon, Kappa and Delta). As expected, the highest neutralizing capacity

95 observed was against the WT strain (Figure 1A). In comparison to the WT strain, there 96 was a significantly decreased neutralizing activity against the Beta, Gamma and Kappa

97 variants $(\mathrm{p}=0.0041, \mathrm{p}=0.0003$ and $\mathrm{p}=0.0294$, respectively). Surprisingly, no statistical

98 differences were observed between the WT strain and the Alpha, Epsilon and Delta 99 variants (Figure 1A). These results suggest that natural infection alone is capable of 100 inducing a broad humoral response to various SARS-CoV-2 strains, including the Delta 101 variant.

102 Vaccination boosts neutralizing capacity against variants in previously 103 infected individuals

104 To assess the humoral immune response to naturally acquired SARS-CoV-2 vs. the 105 mRNA-based COVID-19 vaccine elicited response, we compared the neutralizing capacity 106 of exposed and unexposed subjects after one vaccine dose. Nineteen (19) out of the 21 107 unexposed individuals (90.5\%) produced nAbs (neutralization $\%>30$ ) (Figure 1B and 108 Supplementary Table 4). Similarly, all previously infected individuals reached 109 neutralizing activity greater than $85 \%$ after just one vaccine dose (Figure 1C). This 
medRxiv preprint doi: https://doi.org/10.1101/2021.10.25.21265422; this version posted October 26, 2021. The copyright holder for this preprint (which was not certified by peer review) is the author/funder, who has granted medRxiv a license to display the preprint in perpetuity. It is made available under a CC-BY-NC-ND 4.0 International license .

110 suggests that, in pre-exposed individuals, a single vaccine dose may be sufficient to grant

111 protective immune status against WT SARS-CoV-2. When evaluating the neutralization

112 from unexposed vaccinated individuals against the six VOC, we found significant

113 differences against all except the Delta variant, in comparison with the WT SARS-CoV-2

$114(\mathrm{p}=0.0075$ for Alpha, $\mathrm{p}<0.001$ for Beta and Gamma, $\mathrm{p}=0.0055$ for Epsilon and $\mathrm{p}=$

1150.0012 for Kappa) (Figure 1B). This suggests that the Delta variant, in our population, 116 does not escape neutralization by antibodies induced by mRNA vaccination.

117 Contrastingly, the neutralization activity in all previously exposed vaccinated individuals

118 increased against all variants with no statistical significant differences (Figure 1C).

119 Full vaccination induces limited neutralizing activity against all tested 120 variants in unexposed individuals

121 Next, we evaluated the neutralizing capacity of antibodies after two vaccine doses in both 122 previously exposed and unexposed individuals. All subjects $(n=31)$, regardless of 123 immune status before vaccination, reached neutralization levels greater that 95\% against

124 WT SARS-CoV-2 after receiving a second vaccine dose (Figures 1D and E). This confirms

125 that, in most COVID-19 naïve individuals, two vaccine doses are required to attain full

126 protection.However, when exploring the neutralization against the variants, unexposed

127 individuals gained similar neutralizing activity to the WT SARS-CoV-2 only against the

128 Epsilon and Delta variants $(\mathrm{p}=0.0032$ for Alpha, $\mathrm{p}<0.001$ for Beta and Gamma, and $\mathrm{p}$

$129=0.0035$ for Kappa) (Figure 1D). Therefore, vaccination in unexposed individuals

130 generates a neutralizing response against the Epsilon and Delta variants that is similar to

131 the response against WT SARS-CoV-2 but only after the second dose. Highly relevant,

132 even after the second dose, the neutralization against the other four variants was 133 significantly of lower magnitude compared to the WT. 
medRxiv preprint doi: https://doi.org/10.1101/2021.10.25.21265422; this version posted October 26, 2021. The copyright holder for this preprint (which was not certified by peer review) is the author/funder, who has granted medRxiv a license to display the preprint in perpetuity. It is made available under a CC-BY-NC-ND 4.0 International license .

135 Figure 1. Neutralization capacity of sera from infected and non-infected individuals against SARS-CoV-2 Variants before and after vaccination. The

137 neutralization activity of sera from infected individuals $(n=10)$ and non-infected ones $(n=21)$

138 before and after vaccination was evaluated against the six variants of concern. Dotted line 139 indicates the limit of detection of the sVNT assay, where the percentage of signal inhibition 140 is determined ( $\geq 30 \%$ indicates a positive result). A Normality test (Shapiro Wilk) was 141 performed for all data sets in order to assess the distribution of the data. The significance 142 threshold for all analyses was set at $\mathrm{p}<0.05$. A. Neutralization activity of sera from infected 143 individuals $(\mathrm{n}=10)$ before vaccination. A One-Way ANOVA test with Dunnetts's multiple 144 comparisons test was performed between each of the variants. B. Neutralization activity of 145 sera from healthy individuals $(\mathrm{n}=21)$ after receiving the 1st vaccine dose. A One-Way ANOVA 146 test with Dunn's Kruskal-Wallis multiple comparisons test was performed between each of 147 the variants. C. Neutralization activity of sera from infected individuals $(\mathrm{n}=10)$ after receiving 148 the first vaccine dose. A One-Way ANOVA test with Dunnett's multiple comparisons test was 149 performed between each of the variants. D. Neutralization activity of sera from healthy 150 individuals $(\mathrm{n}=21)$ after receiving the 2nd vaccine dose. A One-Way ANOVA test with Dunn's 151 Kruskal-Wallis multiple comparisons test was performed between each of the variants. E. 152 Neutralization activity of sera from infected individuals $(n=10)$ after receiving the 2nd 153 vaccine dose. A One-Way ANOVA test with Dunnett's multiple comparisons test was 154 performed between each of the variants. F. Neutralization activity of sera from vaccinated 155 individuals, pre-exposed ( $\mathrm{n}=10$, depicted in circles) and healthy ( $\mathrm{n}=21$, depicted in squares), 156 after receiving the 2nd dose was evaluated. A One-Way ANOVA test with Dunn's Kruskal157 Wallis multiple comparisons test was performed between each of the variants. 
medRxiv preprint doi: https://doi.org/10.1101/2021.10.25.21265422; this version posted October 26, 2021. The copyright holder for this preprint (which was not certified by peer review) is the author/funder, who has granted medRxiv a license to display the preprint in perpetuity. It is made available under a CC-BY-NC-ND 4.0 International license .

159 On the other hand, we observed that the previously infected individuals maintained

160 neutralizing capacity against all variants similar to the response against WT SARS-CoV-2

161 strain, denoting a key difference in the dynamics of vaccine-elicited antibodies between

162 exposed vs. unexposed individuals (Figure 1E). This difference can be better appreciated

163 in Figure 1F, where both vaccinated groups are compared after receiving the second dose.

164 Of note, neutralization against the Alpha and Gamma variants did not behave similarly

165 between groups, being of higher magnitude in pre-exposed individuals $(\mathrm{p}=0.0056$ for

166 Alpha and $\mathrm{p}<0.0001$ for Gamma) (Figure 1F).

\section{Discussion}

169 There is still very limited information available on the immunity conferred by the natural

170 infection with the authentic SARS-CoV-2 strain or the mRNA COVID-19 vaccines against

171 the viral variants. Using samples collected during the COVID-19 pandemic, most of them

172 before the documented introduction of the variants in the jurisdiction of Puerto Rico [10,

173 12] we wished to compare the kinetics of the nAbs response in the context of individuals

174 with naturally acquired infection (pre-exposed) and unexposed ones following

175 vaccination via a widely used sVNT [10, 13-15]. Strikingly, we found that natural infection

176 before vaccination confers a broader neutralizing response against different SARS-CoV-2

177 strains, including the Delta variant, compared to the first dose of the COVID-19 mRNA

178 vaccines. These results are consistent with other reports [16-18] and highlight the need

179 for more epidemiological data about the contribution of previously exposed individuals

180 with natural-acquired immunity to herd immunity. Overall, those subjects are scarcely

181 counted in any statistical model. Highly relevant, our results also suggest that two vaccine

182 doses may induce limited protection against some of the circulating variants in naïve

183 individuals. 
A

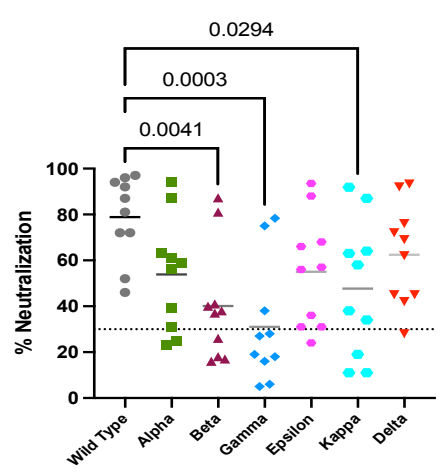

D

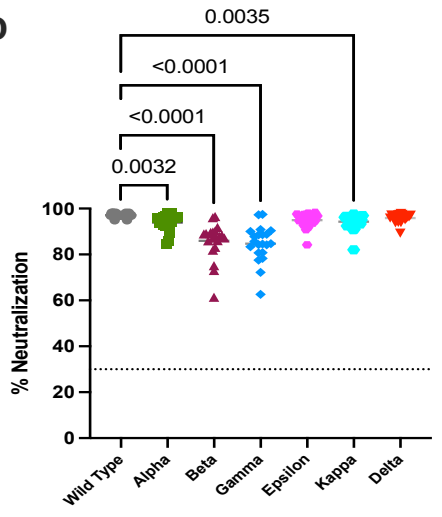

B

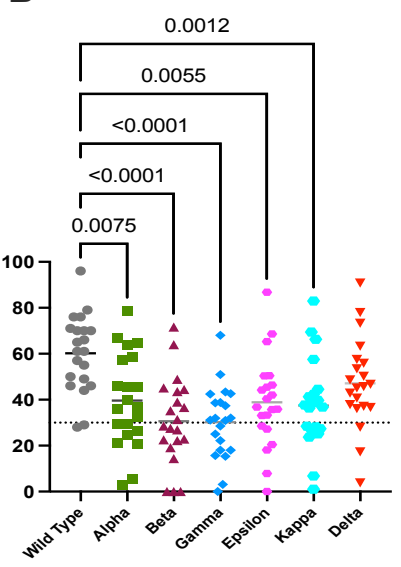

E

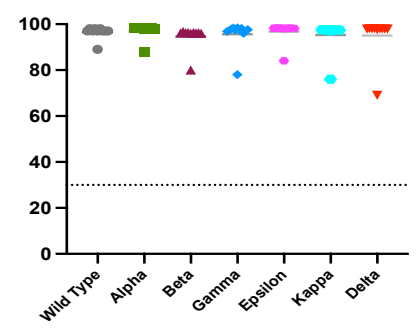

C

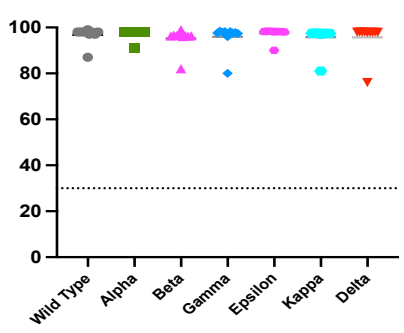

$\mathbf{F}$

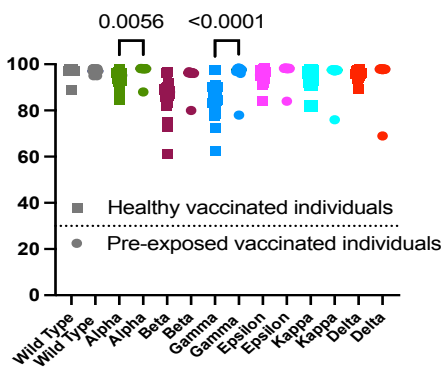

Figure 1. Neutralization capacity of sera from infected and non-infected individuals against SARS-CoV-2

Variants before and after vaccination. The neutralization activity of sera from infected individuals $(n=10)$ and non-infected ones $(n=21)$ before and after vaccination was evaluated against the six variants of concern. Dotted line indicates the limit of detection of the sVNT assay, where the percentage of signal inhibition is determined $(\geq$ $30 \%$ indicates a positive result). A Normality test (Shapiro Wilk) was performed for all data sets in order to assess the distribution of the data. The significance threshold for all analyses was set at $p<0.05$. A. Neutralization activity of sera from infected individuals $(n=10)$ before vaccination. A One-Way ANOVA test with Dunnetts's multiple comparisons test was performed between each of the variants. B. Neutralization activity of sera from healthy individuals ( $n=21)$ after receiving the 1 st vaccine dose. A One-Way ANOVA test with Dunn's Kruskal-Wallis multiple comparisons test was performed between each of the variants. C. Neutralization activity of sera from infected individuals $(n=10)$ after receiving the first vaccine dose. A One-Way ANOVA test with Dunnett's multiple comparisons test was performed between each of the variants. D. Neutralization activity of sera from healthy individuals $(n=21)$ after receiving the $2 n d$ vaccine dose. A One-Way ANOVA test with Dunn's Kruskal-Wallis multiple comparisons test was performed between each of the variants. E. Neutralization activity of sera from infected individuals $(n=10)$ after receiving the $2 n d$ vaccine dose. A One-Way ANOVA test with Dunnett's multiple comparisons test was performed between each of the variants. F. Neutralization activity of sera from vaccinated individuals, pre-exposed $(n=10)$ and healthy $(n=21)$, after receiving the $2 n d$ dose was evaluated. A One-Way ANOVA test with Dunn's Kruskal-Wallis multiple comparisons test was performed between each of the variants. 
medRxiv preprint doi: https://doi.org/10.1101/2021.10.25.21265422; this version posted October 26, 2021. The copyright holder for this preprint (which was not certified by peer review) is the author/funder, who has granted medRxiv a license to display the preprint in perpetuity. It is made available under a CC-BY-NC-ND 4.0 International license .

209 Consistent with other works $[17,19,20]$ our data confirm that subjects previously exposed

210 to SARS-CoV-2 reach levels of protection just after one vaccine dose against all tested

211 variants. Furthermore, we found a limited contribution, if any, of a second vaccine dose

212 in pre-exposed individuals. Those findings strongly suggest that humoral immunity

213 induced by natural infection results in higher quality antibodies [17, 18, 20] and

214 contributes to the expansion of memory B cells producing more cross-reactive antibodies

215 following vaccination [18]. On the other hand, we found that in naïve subjects, a single

216 dose of the COVID-19 mRNA vaccines induces the same magnitude of nAbs against the

217 Delta variant as to the WT strain. That response is improved after the second dose.

218 However, even after a second dose, the magnitude of neutralization against other variants

219 was significantly lower than that of the WT strain.

220 A recent remarkable observational study in Puerto Rico collected hospitalization, death,

221 and vaccination rates data for more than 100,000 laboratory-confirmed SARS-CoV-2

222 infections in a period of 10 months. The study found that the effectiveness of the COVID-

22319 vaccines preventing hospitalizations or death did not change after the Delta variant

224 became dominant [12]. While that study did not segregate, at an individual level, by the

225 vaccination status of the SARS-CoV-2-positive at the time of hospitalization or death, our

226 results are perfectly aligned and provide the immunological rationale for the findings of

227 that study.

228 Recent works suggest that the Delta variant may infect vaccinated individuals, defined as

229 breakthrough infections [21]. In vitro neutralization results using monoclonal antibodies

230 argue that vaccination induces a low level of nAbs against the Delta variant $[8,18,22]$.

231 However, as demonstrated by Liu and colleagues, breakthrough infections by the Delta

232 variant may be due to enhanced viral replication and infectivity, and not to antibody

233 evasion or viral immune escape [4]. This statement is reinforced by the fact that the Delta 
medRxiv preprint doi: https://doi.org/10.1101/2021.10.25.21265422; this version posted October 26, 2021. The copyright holder for this preprint (which was not certified by peer review) is the author/funder, who has granted medRxiv a license to display the preprint in perpetuity. It is made available under a CC-BY-NC-ND 4.0 International license .

234 variant lacks the E484Q mutation that seems to grant antibody resistance to other 235 variants [6]. Thus, it looks like that the Delta variant has developed the perfect evolution 236 balance between transmissibility and virulence to become the dominant strain in 237 circulation. However, there is limited or no data from breakthrough infections by the 238 Delta variant in vaccinated people comparing their prior immune status to SARS-CoV-2.

239 Our findings, together with prior reports on the effectiveness of the cellular immune 240 response against the variants [18, 23-25], warrant a revision of COVID-19 vaccine policies

241 implementation in subjects with prior natural immunity to SARS-CoV-2.

242 We are aware of the limitations of our study, including the small sample size and lack of 243 cellular immunity characterization. The waning of natural or vaccine-elicited immunity 244 remains a possibility outside the follow-up period carried out in this work. However, our 245 results, despite being obtained from a population of different genetic backgrounds, agree 246 with the current ongoing scenario (October 2021) in the United Kingdom (UK). A 247 rampant increase in Delta variant circulation, up 35\% over the two previous weeks, has 248 been observed after all restrictions were lifted in summer 2021 [26]. However, taking into 249 account the high number of cases naturally exposed to the virus and a high vaccination 250 rate in the UK [27], as it would be anticipated by our results, the daily deaths are a tenth 251 of what they were in the prior wave [26, 28]. Considering our findings, a more challenging 252 scenario would be a predominance of other variants like Alpha, Beta, Gamma or Kappa, 253 showing limited neutralization after full vaccination with the mRNA COVID-19 vaccines.

254 To our knowledge, this is the first study conducted in a Hispanic/Latino population 255 impacted by COVID-19, and our findings are a significant contribution to the still lacking 256 population-based studies concerning virus-population dynamics in the setting of 257 vaccination and shed light on the design of the second generation COVID-19 vaccines. 
medRxiv preprint doi: https://doi.org/10.1101/2021.10.25.21265422; this version posted October 26, 2021. The copyright holder for this preprint (which was not certified by peer review) is the author/funder, who has granted medRxiv a license to display the preprint in perpetuity.

It is made available under a CC-BY-NC-ND 4.0 International license .

\section{Conflict of Interest}

260 The authors declare that the research was conducted in the absence of any commercial or

261 financial relationships that could be construed as a potential conflict of interest.

263 Authors Contribution

264 CAS and AME conceptualized the work and supervised the studies and secured the funds. 265 CSC and PP supervised the work and and supported the figures design. EJO and LC

266 execute the experiments. EJO, CSC, DA and CPC coordinate and supervise the cohort's 267 management and follow up. EJO, CSC and PP organized the data for future analysis. TA 268 provided administrative and regulatory support. All authors contribute to the results 269 discussion and analysis. CAS and CSC wrote the initial draft, with the other authors 270 providing insights and concepts.

271

\section{Acknowledgements}

273 Authors want to thank the volunteers that were willing to participate and contribute to 274 science.

275 The Puerto Rico Science, Technology and Research Trust supported research reported in 276 this work under agreement number 2020-00272 to AME and CAS. Also, the University of

277 Puerto Rico contributed with the UPR-COVID-19 Grant to CAS and AME. This work was 278 also supported by 1Uo1CA260541-01 to CAS (NCI/NIAID).

279

280 Corresponding Author contact information

281 Email: carlos.sariol1@upr.edu (CAS) 
medRxiv preprint doi: https://doi.org/10.1101/2021.10.25.21265422; this version posted October 26, 2021. The copyright holder for this preprint (which was not certified by peer review) is the author/funder, who has granted medRxiv a license to display the preprint in perpetuity. It is made available under a CC-BY-NC-ND 4.0 International license .

\section{References}

285 1. Cucinotta D, Vanelli M. WHO Declares COVID-19 a Pandemic. Acta Biomed 2o2o;

$28691: 157-60$.

2. Gavriatopoulou M, Ntanasis-Stathopoulos I, Korompoki E, et al. Emerging treatment strategies for COVID-19 infection. Clin Exp Med 2021; 21:167-79.

3. Aleem A, Akbar Samad AB, Slenker AK. Emerging Variants of SARS-CoV-2 And Novel

290 Therapeutics Against Coronavirus (COVID-19). StatPearls. Treasure Island (FL):

291 StatPearls Publishing. Copyright (C) 2021, StatPearls Publishing LLC., 2021.

292 4. Liu Y, Liu J, Johnson BA, et al. Delta spike P681R mutation enhances SARS-CoV-2

293 fitness over Alpha variant. bioRxiv 2021.

294 5. Gómez-Carballa A, Pardo-Seco J, Bello X, Martinón-Torres F, Salas A.

295 Superspreading in the emergence of COVID-19 variants. Trends Genet 2021.

296 6. Farinholt T, Doddapaneni H, Qin X, et al. Transmission event of SARS-CoV-2 Delta

297 variant reveals multiple vaccine breakthrough infections. medRxiv 2021.

298 7. Pascarella S, Ciccozzi M, Zella D, et al. SARS-CoV-2 B.1.617 Indian variants: Are

299 electrostatic potential changes responsible for a higher transmission rate? J Med Virol

300 2021.

301 8. Planas D, Veyer D, Baidaliuk A, et al. Reduced sensitivity of SARS-CoV-2 variant

302 Delta to antibody neutralization. Nature 2021; 596:276-80.

303 9. Lustig Y, Zuckerman N, Nemet I, et al. Neutralising capacity against Delta (B.1.617.2)

304 and other variants of concern following Comirnaty (BNT162b2, BioNTech/Pfizer)

305 vaccination in health care workers, Israel. Euro Surveill 2021; 26.

306 10. Sariol CA, Pantoja P, Serrano-Collazo C, et al. Function Is More Reliable than

307 Quantity to Follow Up the Humoral Response to the Receptor-Binding Domain of 
medRxiv preprint doi: https://doi.org/10.1101/2021.10.25.21265422; this version posted October 26, 2021. The copyright holder for this preprint (which was not certified by peer review) is the author/funder, who has granted medRxiv a license to display the preprint in perpetuity. It is made available under a CC-BY-NC-ND 4.0 International license .

308 SARS-CoV-2-Spike Protein after Natural Infection or COVID-19 Vaccination. Viruses

2021; 13:1972.

310 11. Taylor SC, Hurst B, Charlton CL, et al. A New SARS CoV-2 Dual Purpose Serology

311 Test: Highly Accurate Infection Tracing and Neutralizing Antibody Response Detection.

312 Journal of Clinical Microbiology 2021:JCM.02438-20.

313 12. Robles-Fontan MM, Nieves EG, Cardona-Gerena I, Irizarry RA. Time-Varying

314 Effectiveness of Three Covid-19 Vaccines in Puerto Rico. medRxiv

315 2021:2021.10.17.21265101.

316 13. Mariën J, Michiels J, Heyndrickx L, et al. Evaluation of a surrogate virus

317 neutralization test for high-throughput serosurveillance of SARS-CoV-2. J Virol

318 Methods 2021; 297:114228.

319 14. Nandakumar V, Profaizer T, Lozier BK, et al. Evaluation of a Surrogate ELISA- Based

320 Severe Acute Respiratory Syndrome Coronavirus 2 (SARS-CoV-2) cPass Neutralization

321 Antibody Detection Assay and Correlation with IgG Commercial Serology Assays. Arch

322 Pathol Lab Med 2021.

323 15. Valcourt EJ, Manguiat K, Robinson A, et al. Evaluation of a commercially-available

324 surrogate virus neutralization test for severe acute respiratory syndrome coronavirus-2

325 (SARS-CoV-2). Diagn Microbiol Infect Dis 2021; 99:115294.

326 16. Shrestha LB, Tedla N, Bull RA. Broadly-Neutralizing Antibodies Against Emerging

327 SARS-CoV-2 Variants. Front Immunol 2021; 12:752003.

328 17. Stamatatos L, Czartoski J, Wan YH, et al. mRNA vaccination boosts cross-variant

329 neutralizing antibodies elicited by SARS-CoV-2 infection. Science 2021.

330 18. Wang Z, Muecksch F, Schaefer-Babajew D, et al. Naturally enhanced neutralizing

331 breadth against SARS-CoV-2 one year after infection. Nature 2o21; 595:426-31. 
medRxiv preprint doi: https://doi.org/10.1101/2021.10.25.21265422; this version posted October 26, 2021. The copyright holder for this preprint (which was not certified by peer review) is the author/funder, who has granted medRxiv a license to display the preprint in perpetuity. It is made available under a CC-BY-NC-ND 4.0 International license .

19. Forgacs D, Jang H, Abreu RB, et al. SARS-CoV-2 mRNA Vaccines Elicit Different

333 Responses in Immunologically Naïve and Pre-Immune Humans. Front Immunol 2021;

$334 \quad 12: 728021$.

335 20. Gazit S, Shlezinger R, Perez G, et al. Comparing SARS-CoV-2 natural immunity to

336 vaccine-induced immunity: reinfections versus breakthrough infections. medRxiv

337 2021:2021.08.24.21262415.

338 21. Thangaraj JWV, Yadav P, Kumar CG, et al. Predominance of delta variant among the

339 COVID-19 vaccinated and unvaccinated individuals, India, May 2021. J Infect 2021.

340 22. Liu C, Ginn HM, Dejnirattisai W, et al. Reduced neutralization of SARS-CoV-2

341 B.1.617 by vaccine and convalescent serum. Cell 2021; 184:4220-36.e13.

342 23. Geers D, Shamier MC, Bogers S, et al. SARS-CoV-2 variants of concern partially

343 escape humoral but not T-cell responses in COVID-19 convalescent donors and

344 vaccinees. Science Immunology 2021; 6:eabj1750.

345 24. Tarke A, Sidney J, Kidd CK, et al. Comprehensive analysis of T cell

346 immunodominance and immunoprevalence of SARS-CoV-2 epitopes in COVID-19

347 cases. Cell Rep Med 2021; 2:100204.

348 25. Tarke A, Sidney J, Methot N, et al. Impact of SARS-CoV-2 variants on the total

349 CD4(+) and CD8(+) T cell reactivity in infected or vaccinated individuals. Cell Rep Med

$350 \quad$ 2021; 2:100355.

351 26. Romano A. Delta's surprise U.K. comeback is a warning sign for the U.S. Yahoo news

352 2021; https://news.yahoo.com/deltas-surprise-uk-comeback-is-a-warning-sign-for-

353 the-us-090008459.html?fr=sycsrp catchall.

354 27. Agency. UHS. Vaccinations in the United Kingdom. Available at:

355 https://coronavirus.data.gov.uk/details/vaccinations Accesed October 21, 2021. 
medRxiv preprint doi: https://doi.org/10.1101/2021.10.25.21265422; this version posted October 26, 2021. The copyright holder for this preprint (which was not certified by peer review) is the author/funder, who has granted medRxiv a license to display the preprint in perpetuity.

28. Agency UHS. Deaths in the United Kingdom. Available at:

357 https://coronavirus.data.gov.uk/details/deaths Accessed October 21, 2021. 